\title{
Polychlorinated biphenyls (PCBs) and hexachlorobenzene (HCB) in the equatorial Indian Ocean: Temporal trend, continental outflow and air-water exchange
}

\author{
Yumei Huang ${ }^{\mathrm{a}, \mathrm{d}}$, Jun $\mathrm{Li}^{\mathrm{a}, *}$, Yue $\mathrm{Xu}^{\mathrm{a}}$, Weihai $\mathrm{Xu}^{\mathrm{b}}$, Zhineng Cheng ${ }^{\mathrm{a}, \mathrm{d}}$, Junwen Liu ${ }^{\mathrm{a}, \mathrm{d}}$, Yan Wang ${ }^{\mathrm{a}}$, \\ Chongguo Tian ${ }^{\mathrm{c}}$, Chunling Luo ${ }^{\mathrm{a}}$, Gan Zhang ${ }^{\mathrm{a}}$ \\ a State Key Laboratory of Organic Geochemistry, Guangzhou Institute of Geochemistry, Chinese Academy of Sciences, Guangzhou 510640, China \\ ${ }^{\mathrm{b}}$ CAS Key Laboratory of Marginal Sea Geology, South China Sea Institute of Oceanology, Chinese Academy of Sciences, Guangzhou 510301, China \\ ${ }^{\mathrm{c}}$ Laboratory of Coastal Zone Environmental Processes, Yantai Institute of Coastal Zone Research, Chinese Academy of Sciences, Yantai, Shandong 264003, China \\ ${ }^{\mathrm{d}}$ Graduate University of Chinese Academy of Sciences, Beijing 100049, China
}

\section{A R T I C L E I N F O}

\section{Keywords:}

PCBs

HCB

Sources

Air-water exchange

The equatorial Indian Ocean

\begin{abstract}
A B S T R A C T
Nineteen pairs of air and seawater samples collected from the equatorial Indian Ocean onboard the Shiyan I from 4/2011 to 5/2011 were analyzed for PCBs and HCB. Gaseous concentrations of $\sum_{\text {ICES }}$ PCBs (ICES: International Council for the Exploration of the Seas) and HCB were lower than previous data over the study area. Air samples collected near the coast had higher levels of PCBs relative to those collected in the open ocean, which may be influenced by proximity to source regions and air mass origins. Dissolved concentrations of $\sum_{\mathrm{ICES}} \mathrm{PCBS}$ and $\mathrm{HCB}$ were $1.4-14 \mathrm{pg} \mathrm{L}^{-1}$ and $0.94-13 \mathrm{pg} \mathrm{L}^{-1}$, with the highest concentrations in the sample collected from Strait of Malacca. Fugacity fractions suggest volatilization of PCBs and HCB from the seawater to air during the cruise, with fluxes of $0.45-34 \mathrm{ng} \mathrm{m}^{-2} \mathrm{~d}^{-1}$ and $0.36-18 \mathrm{ng} \mathrm{m}^{-2}$ $\mathrm{d}^{-1}$, respectively.
\end{abstract}

(c) 2014 Elsevier Ltd. All rights reserved.

\section{Introduction}

Polychlorinated Biphenyls (PCBs) are typical persistent organic pollutants (POPs) of worldwide concern because of their persistence, long-range transport ability, bioaccumulation, and negative effects on people and wildlife. PCBs were finally banned in the late 1970s/early 1980s (de Voogt and Brinkman, 1989) but are still ubiquitous in the environment (Gioia et al., 2011). Deep oceans are considered as a final sink for POPs, removing them from the "recyclable pool" in the environment (Dachs et al., 2002). Net deposition of PCBs has been observed in the North Atlantic and Arctic Oceans (Gioia et al., 2008a,b). However, volatilization of PCBs from the ocean to lower air has also been estimated in the open Pacific Ocean (Zhang and Lohmann, 2010) and tropical Atlantic Ocean (Lohmann et al., 2012), suggesting oceans could also act as a secondary source of atmospheric PCBs in the environment.

The equatorial Indian Ocean is surrounded by tropical developing countries, which have received large amounts of e-waste, like India, Pakistan, Malaysia, Vietnam and the Philippines (Robinson, 2009). India, Pakistan and Bangladesh continue to release PCBs to the Indian Ocean from the ship-breaking industry, with up to 0.25-0.8 metric tons of PCBs generated per scrapped merchant

\footnotetext{
* Corresponding author. Tel.: +86 208529 1508; fax: +86 2085290706 .

E-mail address: junli@gig.ac.cn (J. Li).
}

ship (Wurl et al., 2006). The air-water exchange process in the oceans is of great importance in controlling the environmental fate of POPs, and learning about sources of POPs in the adjacent countries (Iwata et al., 1993). The study of air-water exchange in the equatorial Indian Ocean could date back to Iwata et al. (1993), who suggested positive-to-negative range of fluxes for PCBs in the Bay of Bengal and Arabian Sea.

The aims of the present study are to: (1) update the data on the concentrations of PCBs and HCB in the air and surface water phase in the equatorial Indian Ocean, (2) discuss the spatial distribution and possible sources of PCBs, and (3) estimate the directions and fluxes of air-water exchange of PCBs and HCB in the target region. The study is based on 19 pairs of lower air and surface seawater samples that were collected from the equatorial Indian Ocean in 2011 onboard the Chinese research vessel Shiyan I.

\section{Materials and methods}

\subsection{Sample collection}

Onboard the Shiyan I of South China Sea Institute of Oceanology, 19 pairs of air and surface seawater samples were taken from the equatorial Indian Ocean $\left(0-6^{\circ} \mathrm{E}, 80-98.5^{\circ} \mathrm{N}\right.$, Fig. 1, Table S1) from April 12th to May 4th, 2011. Air samples were taken via a 


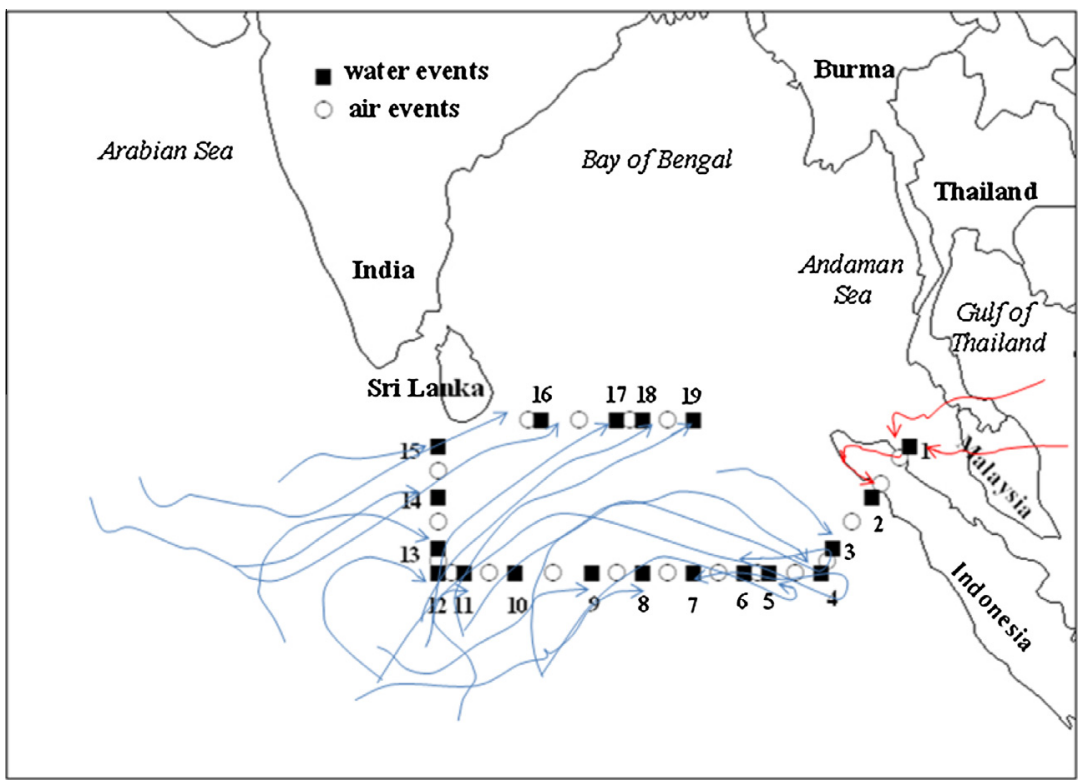

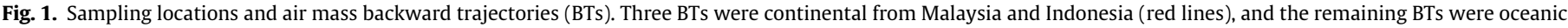
from the Indian Ocean (blue lines). (For interpretation of the references to colour in this figure legend, the reader is referred to the web version of this article.)

high-volume air sampler placed in the windward side on the foredeck of the ship. About $200-500 \mathrm{~m}^{3}$ of air was drawn through a quartz fiber filter and subsequently through a polyurethane foam (PUF) plug. At each site, about 70-120 L of surface seawater was collected using a seawater-cleaned metal bucket and filtered through a precombusted $\left(4 \mathrm{~h}\right.$ at $\left.450{ }^{\circ} \mathrm{C}\right) 150 \mathrm{~mm}$ diameter glass fiber filter (Gelman Type A/E, nominal pore size: $1 \mu \mathrm{m}$ ). Then the water sample was passed through a Teflon column (i.d.: $25 \mathrm{~mm}$, length: $20 \mathrm{~mm}$ ) packed with pretreated resin (XAD-2 and XAD-4, $1: 1 \mathrm{v} / \mathrm{v}$ ). All the samples (filters, PUFs and Teflon columns) were stored at $-20^{\circ} \mathrm{C}$ until analysis.

\subsection{Sample preparation}

The PUF samples spiked with recovery surrogates $(\mathrm{TCmX}$ PCB209 and ${ }^{13}$ C-PCB141) were Soxhlet extracted with dichloromethane (DCM) and further purified on a multilayer silica gel-alumina column packed with $3 \mathrm{~cm}$ neutral alumina (3\% deactivated), $3 \mathrm{~cm}$ neutral silica gel ( $3 \%$ deactivated), $3 \mathrm{~cm}$ sulfuric acid silica gel ( $50 \%$ by mass), and $1 \mathrm{~cm}$ anhydrous $\mathrm{Na}_{2} \mathrm{SO}_{4}$ from bottom to top. $30 \mathrm{~mL}$ of $\mathrm{DCM} /$ hexane (v:v 1:1) were eluted to collect the PCB and HCB fraction. The XAD resin spiked with the above surrogates was ultrasonically extracted with methanol $(3 \times 50 \mathrm{~mL})$ and DCM $(3 \times 50 \mathrm{~mL})$. The extract was combined with $200 \mathrm{~mL}$ saturated $\mathrm{NaCl}$ solution, further extracted using DCM $(3 \times 50 \mathrm{~mL})$, dried with $15 \mathrm{~g}$ anhydrous $\mathrm{Na}_{2} \mathrm{SO}_{4}$, concentrated and purified as the PUF samples. Concentrated fraction was solvent exchanged to hexane, further concentrated to a volume of about $50 \mu \mathrm{L}$ under subtle nitrogen. ${ }^{13} \mathrm{C}$-PCB138 was added as an internal standard for instrumental analysis. Before use, neutral silica gel and neutral alumina was each Soxhlet-extracted with DCM for $48 \mathrm{~h}$, and baked for $12 \mathrm{~h}$ at $180^{\circ} \mathrm{C}$ and $250{ }^{\circ} \mathrm{C}$, respectively. Anhydrous $\mathrm{Na}_{2} \mathrm{SO}_{4}$ was baked at $450{ }^{\circ} \mathrm{C}$ for $12 \mathrm{~h}$ before use. Filter samples were not analyzed in this study.

\subsection{Instrumental analysis}

Twenty-one types of PCBs (PCB18, 28, 44, 52, 66, 77, 81,101, $105,114,118,123,126,128,138,153,156,157,167,169$ and 180 ) and HCB were measured on an Agilent 7890/7000 GC-MS/
MS with a HP-5MS capillary column $(30 \mathrm{~m} \times 0.25 \mathrm{~cm} \times 0.25 \mathrm{~mm}$, Agilent, CA, USA). The mass spectrometer was operated with an EI source $(-70 \mathrm{eV})$ in multiple reaction monitoring (MRM) mode. Specific MRM parameters for the target compounds are shown in Table S2. The temperatures of the transfer line, injector interface, and ion source were set at $280^{\circ} \mathrm{C}, 250^{\circ} \mathrm{C}$, and $230^{\circ} \mathrm{C}$, respectively. The GC oven temperature was set at $80^{\circ} \mathrm{C}$ for $0.5 \mathrm{~min}$, then $20{ }^{\circ} \mathrm{C} \mathrm{min}^{-1}$ to $160^{\circ} \mathrm{C}, 4^{\circ} \mathrm{C} \mathrm{min}^{-1}$ to $240{ }^{\circ} \mathrm{C}$, and finally $10^{\circ} \mathrm{C} \mathrm{min}^{-1}$ to $295^{\circ} \mathrm{C}$, and hold for $10 \mathrm{~min} .1 \mu \mathrm{L}$ of sample was injected in splitless mode. Helium was used as carrier gas $\left(1 \mathrm{~mL} \mathrm{~min}^{-1}\right)$. Collision induced dissociation (CID) gas and quench gas in collision cell were nitrogen and helium at the flow rate of $1.5 \mathrm{~mL} \mathrm{~min}^{-1}$ and $2.25 \mathrm{~mL} \mathrm{~min}^{-1}$, respectively. The scan time ranged from $0.234 \mathrm{~s}$ to $0.255 \mathrm{~s}$ for all the segments.

\section{4. $Q A / Q C$}

Three laboratory blanks, four PUF field blanks and two XAD field blanks were analyzed. For air samples, the recoveries were $97 \pm 7.2 \%, 63 \pm 13 \%$, and $110 \pm 11 \%$ for ${ }^{13} \mathrm{C}-\mathrm{PCB} 141, \mathrm{TCmX}$, and PCB 209, respectively. For water samples, the equivalent values were $97 \pm 10 \%, 71 \pm 9.5 \%$, and $100 \pm 18 \%$, respectively. The method detection limits (MDLs) of the target PCBs and HCB ranged from 0.02 to $0.08 \mathrm{pg} \mathrm{m}^{-3}$ for the air samples, and from 0.05 to $0.25 \mathrm{pg} \mathrm{L}^{-1}$ for the water samples. The target compounds were under the MDLs in the laboratory blanks. Trace amounts of PCB18, 28, 44, 52 and HCB were detected in the PUF field blanks $(0.03-$ $0.12 \mathrm{pg} \mathrm{m}^{-3}$ ), and $0.10-0.32 \mathrm{pg} \mathrm{L}^{-1}$ of PCB18, 28, 77, 81, 118, and HCB were detected in the XAD field blanks. The reported PCB concentrations in the air and seawater samples in this study were corrected by deducting the average values in PUF and XAD field blanks, respectively, and were not recovery corrected.

\subsection{Air mass back trajectories (BTs)}

In order to assess the possible sources of PCBs and HCB in the lower air samples, air mass origins along the sampling segments were analyzed using the NOAA's HYSPLIT model (Draxler and Rolph, 2003). 5-day back trajectories were calculated at the beginning 
and end of each sampling event in coordinated universal time (UTC) at $10 \mathrm{~m}$ above sea level. The results are shown in Fig. 1.

\section{Results and discussion}

\subsection{Concentrations in the air and temporal trend}

PCBs: Table 1 summarizes the results of air and seawater PCB concentrations. The sum of the 21 measured PCBs $\left(\sum_{21} \mathrm{PCBs}\right)$ in the air ranged from 2.0 to $29 \mathrm{pg} \mathrm{m}^{-3}$. Tri- and tetra-PCBs dominated and constituted $64 \pm 21 \%$ and $32 \pm 22 \%$, respectively, of the $\sum_{21}$ PCBs. The concentrations of $\sum_{\text {ICES }}$ PCBs (PCB 28, 52, 101, 118, 138,153 , and 180 , identified by the International Council for the Exploration of the Seas (ICES) as markers of the degree of contamination) were $1.4-22 \mathrm{pg} \mathrm{m}^{-3}$ and contributed $64-77 \%$ to the total PCBs. PCB28 is the predominant congener in most samples, with concentrations ranging from 1.2 to $11 \mathrm{pg} \mathrm{m}^{-3}$, except for air samples No. 2 and 3, in which PCB 52 was the most abundant congener with concentration of $22 \mathrm{pg} \mathrm{m}^{-3}$ and $15 \mathrm{pg} \mathrm{m}^{-3}$, respectively. Concentrations of higher chlorinated PCB101, 118, 138 and 153 were below $1 \mathrm{pg} \mathrm{m}^{-3}$ in all samples. PCB138 was only detected in four samples. PCB180 and the nine dioxin-like PCB congeners (PCB105, 114, 123, 126, 128, 156, 157, 167 and 169) were under detection limit in all air samples.

The concentration range of $\sum_{\text {ICES }} P C B$ in this study was lower than the values reported over the North Pacific Ocean in 2008 (28-103 $\mathrm{pg} \mathrm{m}^{-3}$ ) (Zhang and Lohmann, 2010), and the open Atlantic in $2001\left(4.5-120 \mathrm{pg} \mathrm{m}^{-3}\right.$ ) (Jaward et al., 2004) and in 2005 (3.7-220 $\mathrm{pg} \mathrm{m}^{-3}$ ) (Gioia et al., 2008a), and was similar to the measurements by Gioia et al. (2008b) over the Arctic (range: 0.76-43 $\mathrm{pg} \mathrm{m}^{-3}$, mean: $7 \mathrm{pg} \mathrm{m}^{-3}$ ) and Zhang and Lohmann (2010) over the South Pacific Ocean (1.5-36 $\mathrm{pg} \mathrm{m}^{-3}$ ).

Reported data on PCB concentrations in the equatorial Indian Ocean are limited. The latest data showed that the concentration of $\sum_{7}$ PCBs (sum of PCB31/28, 52, 90/101, 118, 153/132, 138, and 180) ranged from 5 to $73 \mathrm{pg} \mathrm{m}^{-3}$ with an average of $30 \mathrm{pg} \mathrm{m}^{-3}$ in the air over the Andaman Sea and Bay of Bengal in 2008 (Gioia et al., 2012), which were much higher than those measured in this study. Wurl et al. (2006) observed concentrations 6.8-16.1 $\mathrm{pg} \mathrm{m}^{-3}$ for $\sum_{38} \mathrm{PCBs}$ in two air samples collected in the study area in 2005 , with PCB 18, 44, 49, 52, 70, 74, 87, 95, 101 and $110+82$ being the major congeners. Substantially higher concentrations of $\sum_{40} \mathrm{PCBs}$ (19-710 $\mathrm{pg} \mathrm{m}^{-3}$ ) were observed in the air over the Bay of Bengal and Arabian Sea in 1989-1990 (Iwata et al., 1993). Comparison with these data sets should be treated cautiously because different PCB congeners were measured in different studies. However, since low chlorinated PCBs are the dominant congeners in these studies, the comparison could indicate a significant decrease of $\mathrm{PCB}$ concentrations in the air over the equatorial Indian Ocean since 1990s. This may be related to the ban history of PCBs in the adjacent countries (UNEP, 2002). In addition, the variations of PCB concentrations measured in those studies over the same areas may be affected by the origin of air masses when the samples were collected. For example, continental air masses related to land outflow may give rise to the gaseous PCB levels in the Bay of Bengal and Arabian Sea in 1989 (Wurl et al., 2006), while the low gaseous PCB levels observed in 2005 may be related to the oceanic air masses (Wurl et al., 2006). Partly oceanic and partly continental air masses arrived when the air samples were collected in this study and in 2008 (Gioia et al., 2012).

$H C B$ : $\mathrm{HCB}$ concentrations in the air were $2.2-17 \mathrm{pg} \mathrm{m}^{-3}$, with an average value of $6.2 \pm 3.9 \mathrm{pg} \mathrm{m}^{-3}$. The concentration range is similar to those reported over the North Atlantic Ocean (3.6$17.6 \mathrm{pg} \mathrm{m}^{-3}$ ) (Zhang et al., 2012) and the open Atlantic Ocean $\left(0.8-21.9 \mathrm{pg} \mathrm{m}^{-3}\right.$ ) (Gioia et al., 2012), but is lower than those in Canadian Arctic Ocean (48-71 $\mathrm{pg} \mathrm{m}^{-3}$ ) (Wong et al., 2011), the eastern Arctic region (23-87 $\mathrm{pg} \mathrm{m}^{-3}$ ) (Lohmann et al., 2009), and the open Pacific (14-89 $\mathrm{pg} \mathrm{m}^{-3}$ ) (Zhang and Lohmann, 2010). Higher concentrations $\left(4.6-38 \mathrm{pg} \mathrm{m}^{-3}, 24 \pm 11 \mathrm{pg} \mathrm{m}^{-3}\right.$ ) were observed in the air over the Andaman Sea and Bay of Bengal in 2008 (Gioia et al., 2012).

\subsection{Concentrations in the seawater}

PCBs: $\sum_{21} \mathrm{PCBs}$ in the surface seawater ranged from 2.7 to $25 \mathrm{pg} \mathrm{L}^{-1}$, with an average value of $7.5 \pm 5.4 \mathrm{pg} \mathrm{L}^{-1}$. Similar to the profile in the air samples, tri-and tetra-PCBs dominated, accounting for $58 \pm 12 \%$ and $33 \pm 11 \%$, respectively, of total PCBs. Concentrations of $\sum_{\mathrm{ICES}} \mathrm{PCBs}$ were $1.4-14 \mathrm{pg} \mathrm{L}^{-1}$ and its contribution to $\sum_{21}$ PCBs (27-66\%) is less than that in the air. PCB28 is the predominating congener, with concentrations varying from 0.89 to $10 \mathrm{pg} \mathrm{L}^{-1}$. PCB101, 118, 138 and 153 displayed concentrations lower than $1 \mathrm{pg} \mathrm{L}^{-1}$, and were detectable in 16-95\% samples. PCB180 and the other dioxin-like PCBs (PCB 105, 126, 128, 156, 157, 167 and 169) were under detection limit in all samples.

Compared to those reported in other oceans, the $\sum_{\text {ICES }} \mathrm{PCB}$ concentrations in this study were similar to the recent finding in the North Pacific (0.2-15 $\left.\mathrm{pg} \mathrm{L}^{-1}\right)$, and higher than that in the South Pacific (0.3-7.8 $\mathrm{pg} \mathrm{L}^{-1}$ ) (Zhang and Lohmann, 2010). Much lower values were observed in the Atlantic (0.017-1.7 $\mathrm{pg} \mathrm{L}^{-1}$ ) (Gioia et al., 2008a) and the Arctic ( $<1 \mathrm{pg} \mathrm{L}^{-1}$ ) (Gioia et al., 2008b). Iwata et al. (1993) reported concentrations of $13-46 \mathrm{pg} \mathrm{L}^{-1}$ for $\sum{ }_{40} \mathrm{PCBs}$ in the Bay of Bengal and Arabian Sea in 1989-1990.

HCB: To our knowledge, HCB concentration is reported for the first time in the seawater of the equatorial Indian Ocean, with a range of $0.94-13 \mathrm{pg} \mathrm{L}^{-1}$, which is higher than those in the open Pacific (0.4-1.6 $\mathrm{pg} \mathrm{L}^{-1}$ ) (Zhang and Lohmann, 2010), the South Atlantic (1.9-3.3 $\mathrm{pg} \mathrm{L}^{-1}$ ) (Booij et al., 2007) and the North Atlantic

Table 1

Summary of PCB and HCB concentrations in the air and seawater of the equatorial Indian Ocean.

\begin{tabular}{|c|c|c|c|c|c|c|c|c|}
\hline \multirow[t]{2}{*}{ Compound } & \multicolumn{4}{|c|}{ Air concentration $\left(\mathrm{pg} \mathrm{m}^{-3}\right)$} & \multicolumn{4}{|c|}{ Water concentration $\left(\mathrm{pg} \mathrm{L}^{-1}\right)$} \\
\hline & Minimum & Maximum & Mean & SD & Minimum & Maximum & Mean & SD \\
\hline РCB28 & 0.28 & 11 & 4.8 & 2.9 & 0.89 & 10 & 3.2 & 2.1 \\
\hline PCB52 & 0.22 & 22 & 2.9 & 5.6 & n.d. & 1.7 & 0.24 & 0.45 \\
\hline PCB101 & n.d. & 0.55 & 0.16 & 0.17 & n.d. & 0.74 & 0.28 & 0.17 \\
\hline PCB118 & n.d. & 0.20 & 0.09 & 0.06 & n.d. & 0.55 & 0.11 & 0.14 \\
\hline PCB153 & n.d. & 0.34 & 0.12 & 0.09 & n.d. & 0.52 & 0.10 & 0.14 \\
\hline PCB138 & n.d. & 0.21 & 0.03 & 0.06 & n.d. & 0.14 & 0.02 & 0.05 \\
\hline PCB180 & n.d. & n.d. & n.d. & n.d. & n.d. & n.d. & n.d. & n.d. \\
\hline$\sum_{\mathrm{ICES}} \mathrm{PCBS}$ & 1.4 & 22 & 8.1 & 5.1 & 1.4 & 14 & 4.0 & 2.6 \\
\hline$\sum_{21} \mathrm{PCBs}$ & 2.0 & 29 & 12 & 6.9 & 2.7 & 25 & 7.5 & 5.4 \\
\hline $\mathrm{HCB}$ & 2.2 & 17 & 6.2 & 3.9 & 0.94 & 13 & 4.0 & 3.0 \\
\hline
\end{tabular}

n.d.: Not detected. 
Ocean (0.1-0.8 $\mathrm{pg} \mathrm{L}^{-1}$ ) (Zhang et al., 2012). Similar concentrations were observed in the eastern Arctic (0.85-9.6 pg L ${ }^{-1}$ ) (Lohmann et al., 2009) and a narrower range was observed in the Canadian Arctic regions (4.0-6.4 $\mathrm{pg} \mathrm{L}^{-1}$ ) (Wong et al., 2011).

\subsection{Spatial variation and continental outflow}

Fig. 2 shows the spatial distribution of $\sum_{\text {ICES }} \mathrm{PCBs}$ and $\mathrm{HCB}$ in the air and water phases along the sampling cruise.

Air samples with continental air masses from over the land of Indonesia and Malaysia showed higher levels of PCBs than those collected in the open ocean (Figs. 1 and 2), suggesting continental outflow of PCBs. Although the usage of PCBs has been banned in those countries (UNEP, 2002), the important sources such as older PCB-containing equipments, landfill, and incineration of e-waste are continuing to release PCBs to the environment (Breivik et al., 2007). A recent study suggested that large quantities of e-waste have been exported to Malaysia (Robinson, 2009). Furthermore, accidental release from fires may be a possible source, as PCBs previously deposited in the soil would volatilize when extensive biomass burning taking place in the continents (Eckhardt et al., 2007). High PCB concentration was also observed in the air sample No. 16 collected near Sri Lanka and India (Fig. 2), which may be related to continental outflow from India, where substantially high concentrations have been detected in the air (Pozo et al., 2011; Zhang et al., 2008). For example, $\sum$ ICES PCB concentrations higher by a factor of $\sim 30$ than this study were measured by Zhang et al. (2008) in Mumbai, Bangalore, and Kolkata with levels of 253, 243, and $239 \mathrm{pg} \mathrm{m}^{-3}$, respectively. Emissions from the intensive ship-breaking activities and storage of obsolete equipment (Zhang et al., 2008), landfill, and incineration of e-waste were important potential sources for PCBs in India (Breivik et al., 2011).

In the water phase, the highest concentration of $\sum_{\mathrm{ICES}} \mathrm{PCBs}$ and HCB was observed in site 1, which is located at the Strait of Malacca between Malaysia and Indonesia. This high concentration may be related to the riverine output of PCBs and HCB from Indonesia or Malaysia. In the remaining sites, small variations were observed, with a range of 1.4-5.5 $\mathrm{pg} \mathrm{L}^{-1}$ for $\sum_{\mathrm{ICES}} \mathrm{PCBs}$ and $0.94-9.0 \mathrm{pg} \mathrm{L}^{-1}$ for $\mathrm{HCB}$, respectively.

\subsection{Air-water exchange of $P C B$ s and $H C B$}

\subsubsection{Fugacity fractions}

Fugacity fraction $(f f)$ was used to assess the air-water exchange direction of PCBs and HCB. ff was calculated according to the following equations (Zhang et al., 2007):

$f_{a}=C_{a} R T$
$f_{w}=C_{w} H$

$f f=f_{w} /\left(f_{w}+f_{a}\right)$

where $f_{a}$ and $f_{w}$ are fugacity of chemical in the air and water, $C_{a}$ and $C_{w}$ are concentrations of chemical in the air and water $\left(\mathrm{mol} \mathrm{m}^{-3}\right), R$ is the gas constant $\left(8.314 \mathrm{~Pa} \mathrm{~m}^{3} \mathrm{~mol}^{-1} \mathrm{~K}^{-1}\right), T$ is the absolute temperature $(\mathrm{K})$, and $H$ is the Henry's law constant $\left(\mathrm{Pa} \mathrm{m}^{3} \mathrm{~mol}^{-1}\right)$. $f f=0.5$ indicates air-water equilibrium, $f f<0.5$ indicates net deposition to the water, and $f f>0.5$ indicates volatilization from the water (Zhang et al., 2007).

The $f f$ values of PCB 18, 28, 44, 52, 66, 101, 118, 153, and HCB were estimated in this study, while ff of other PCB congeners were not calculated because of their low detection frequency. An average temperature value of $303 \mathrm{~K}$ in the surface seawater was used for the correction of $H$ values. $H$ values of PCB 28, 52, 101, 118 and 153 were derived from the equation for FAVs (Final Adjusted Values) compiled by Li et al. (2003) and $H$ values of PCB 18, 44 and 66 were taken by Bamford et al. (2002). $H$ of HCB was calculated according to the equation established by Jantunen and Bidleman (2006) and adjusted considering the salting out effect (Su et al., 2006). Uncertainty of $45 \%$ was assigned for the $f f$ calculation, based on the error in the measurement of $C_{a}, C_{w}$, and $H$ values (Zhang et al., 2007), which means that ff between 0.275 and 0.725 is considered as not significantly different from air-water equilibrium (Fig. 3).

As shown in Fig. 3, net volatilization of PCBs from the equatorial Indian Ocean was observed at most sampling sites, indicating that the water phase is a secondary source of PCBs in the lower air. Near equilibrium was found for PCB 18 and 44 at several sites with $\mathrm{ff}$ ranging from 0.375 to 0.725 . Net deposition was observed for PCB 52, 66, and 153 at some sampling sites when these compounds were under detection limits in the water phase, with $f f$ value of zero. Volatilization of PCBs was also observed in the open Pacific Ocean during 2006-2007 (Zhang and Lohmann, 2010) and the tropical Atlantic in 2009 (Lohmann et al., 2012). Whereas, Gioia et al. (2008a,b) observed net deposition of PCBs dominated in the North Atlantic and Arctic, and equilibrium of PCBs in the South Atlantic.

With respect to $\mathrm{HCB}$, net volatilization was observed at all sites in this study (Fig. 3), which may be in part due to the high $H$ value (57.4 $\mathrm{Pa} \mathrm{m}^{3} \mathrm{~mol}^{-1}$ ) of HCB used in the study area with high water temperatures. Net volatilization or close to equilibrium was deduced for HCB in the tropical Atlantic north of the equator (Lohmann et al., 2012). Air-water equilibrium or near equilibrium and deposition of HCB was observed in the oceans with much lower water temperatures, such as the North Atlantic (Lohmann et al., 2009; Zhang et al., 2012) and Arctic Ocean (Lohmann et al., 2009;
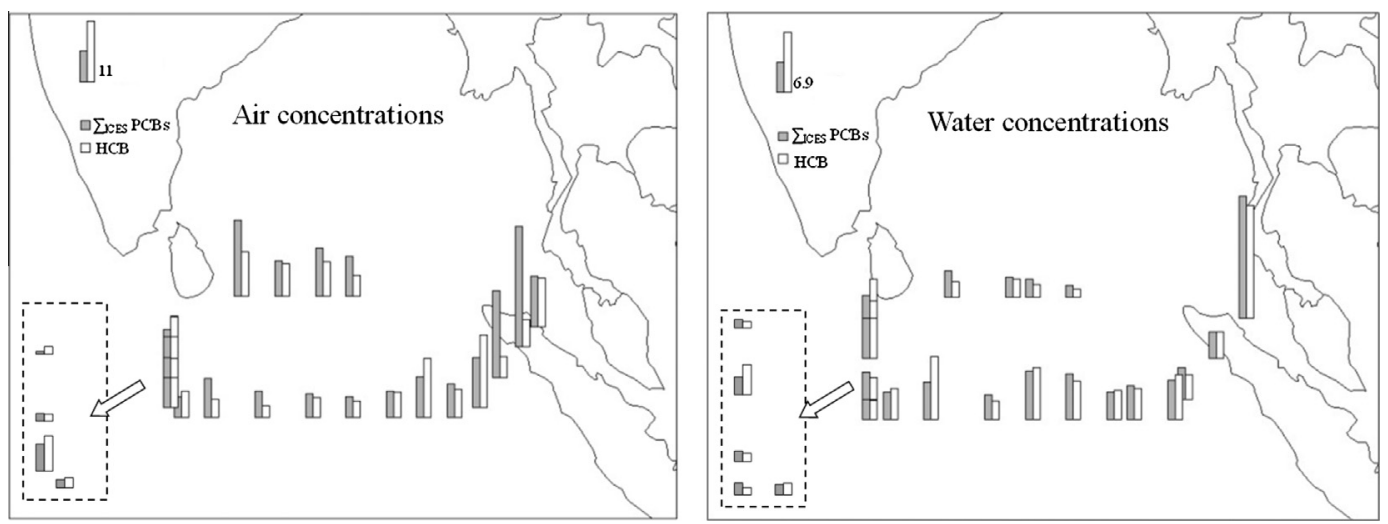

Fig. 2. Spatial distribution of $\sum_{\mathrm{ICES}} \mathrm{PCBs}$ and $\mathrm{HCB}$ in the air $\left(\mathrm{pg} \mathrm{m}^{-3}\right)$ and seawater $\left(\mathrm{pg} \mathrm{L}^{-1}\right)$ of the equatorial Indian Ocean. 

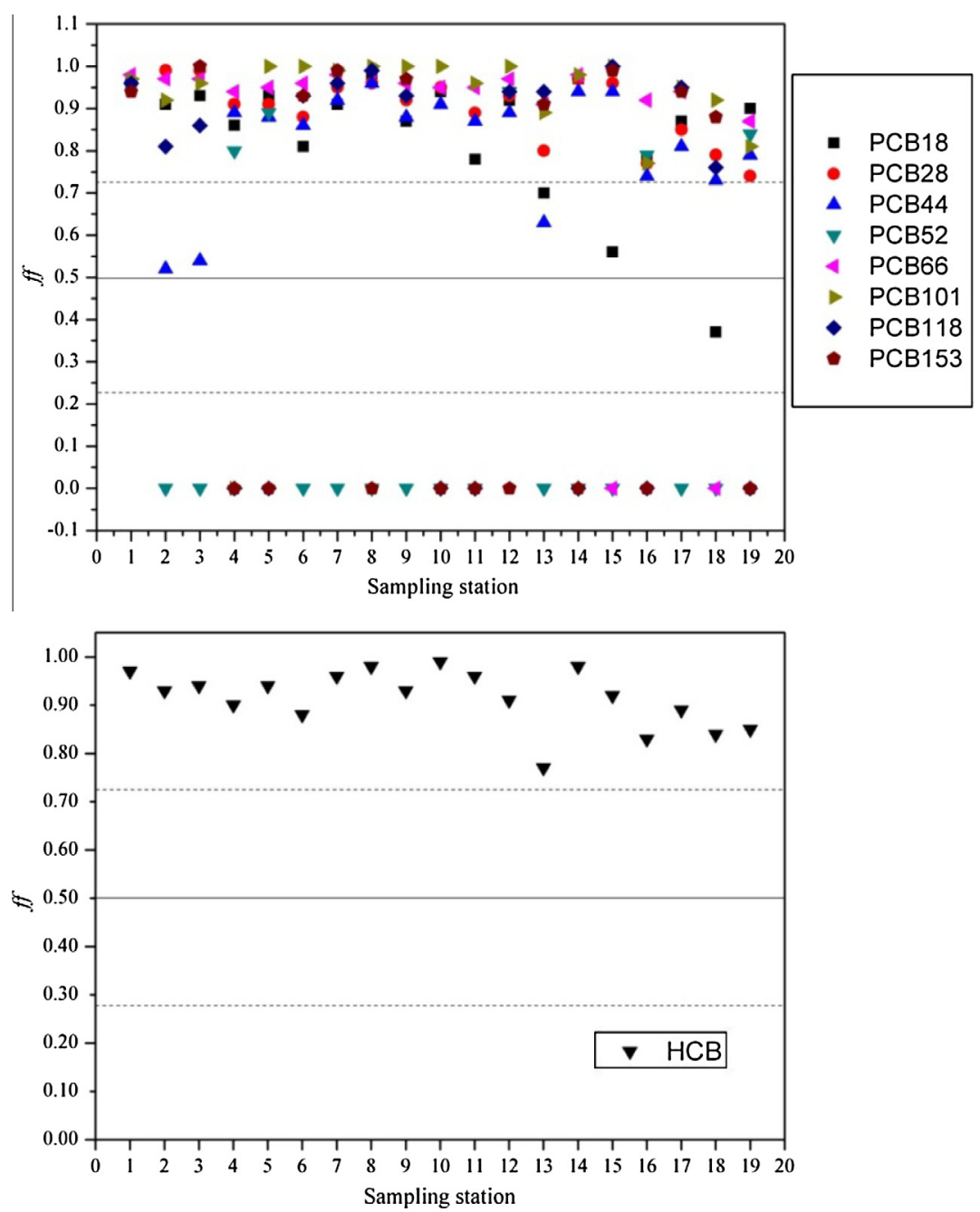

Fig. 3. Water-air fugacity fractions (ff) of selected PCBs and HCB along the sampling cruise. An uncertainty of $45 \%$ was used and marked as dashed lines in this figure.

Su et al., 2006; Wong et al., 2011). Equilibrium or near equilibrium of HCB was also indicated in the Pacific Ocean (Zhang and Lohmann, 2010).

\subsubsection{Air-water exchange flux}

Air-water gas exchange fluxes $\left(F_{a / w}, \mathrm{ng} \mathrm{m}^{-2} \mathrm{~d}^{-1}\right)$ were estimated using a modified version of Deacon's boundary layer model (Schwarzenbach et al., 2003). Water is chosen as the reference phase, and a positive $F_{a / w}$ value indicates a net flux from the water to the atmosphere:

$F_{a / w}=v_{i a / w} \times\left[C_{w}-C_{a} R T / H\right]$

where $C_{w}, C_{a}, R, T$, and $H$ are the same as defined above, $v_{i a / w}\left(\mathrm{~m} \mathrm{~d}^{-1}\right)$ is the overall air-water gas exchange mass transfer coefficient (MTC) for chemical $i$, and was calculated according to Schwarzenbach et al. (2003).

In this study, the flux of $\sum_{8}$ PCBs (PCB18, 28, 44, 52, 66, 101, 118 and 153) ranged from 0.45 to $34 \mathrm{ng} \mathrm{m}^{-2} \mathrm{~d}^{-1}$, with a mean value of $3.9 \mathrm{ng} \mathrm{m}^{-2} \mathrm{~d}^{-1}$. This range is similar to the values over the Pacific Ocean, where the flux of $\sum_{15} \mathrm{PCBs}$ was from -0.4 to $30 \mathrm{ng} \mathrm{m}^{-2} \mathrm{~d}^{-1}$ (Zhang and Lohmann, 2010). Much lower fluxes were observed in the Atlantic ( -7 to $0.02 \mathrm{ng} \mathrm{m}^{-2} \mathrm{~d}^{-1}$ for $\sum_{5} \mathrm{PCBs}$ ) (Gioia et al., 2008a) and the North Atlantic and Arctic Ocean (-4 to $0.08 \mathrm{ng} \mathrm{m}^{-2} \mathrm{~d}^{-1}$ for $\sum_{4} \mathrm{PCBs}$ ) (Gioia et al., 2008b), where deposition dominated. Tri- (PCB18 and 28) and tetra (PCB 44, 52 and 66 ) dominated the $\sum_{8} \mathrm{PCBs}$ fluxes in this study, accounting for
$92 \%$ of the average value. This finding is similar to the observation in the Atlantic and Arctic Ocean, where tri- and tetra-PCBs contributed more than 70\% to the total PCB fluxes (Gioia et al., 2008a,b). However, Zhang and Lohmann (2010) found that di- and tri-PCBs dominated the fluxes of $\sum_{15} \mathrm{PCBs}$ in the open Pacific, with abundance more than $80 \%$ at most sites.

The flux of HCB in this study ranged from 0.36 to $18 \mathrm{ng} \mathrm{m}^{-2} \mathrm{~d}^{-1}$, with an average of $2.2 \mathrm{ng} \mathrm{m}^{-2} \mathrm{~d}^{-1}$. Higher fluxes from the air to water were observed in the Canadian Arctic ( -6.1 to $-15 \mathrm{ng} \mathrm{m}^{-2}$ $\mathrm{d}^{-1}$, mean $=-9.6 \pm 2.7 \mathrm{ng} \mathrm{m}^{-2} \mathrm{~d}^{-1}$ ) (Wong et al., 2011) and North Atlantic ( -30.33 to $-3.45 \mathrm{ng} \mathrm{m}^{-2} \mathrm{~d}^{-1}$, mean $=-14.8 \pm 7.5 \mathrm{ng} \mathrm{m}^{-2}$ $\mathrm{d}^{-1}$ ) (Zhang et al., 2012).

Pearson correlation analysis suggested that fluxes were mostly determined by the concentration gradient $\left(C_{w}-C_{a} R T / H\right)$, with correlation coefficients of $0.849(p<0.001)$ and $0.775(p<0.001)$, respectively, for $\sum_{8} \mathrm{PCBs}$ and $\mathrm{HCB}$. Wind speed was also correlated with the fluxes $\left(R=0.541\right.$ and $p=0.017$ for $\sum_{8} \mathrm{PCBs} ; R=0.514$ and $p=0.024$ for $\mathrm{HCB}$ ). This is consistent with the result in the Pacific Ocean, where PCB fluxes were mostly driven by the concentration gradient and influenced by wind speed as well (Zhang and Lohmann, 2010).

\section{Conclusion}

In this study, a significant decline was observed in the concentrations of PCBs in the air over the equatorial Indian Ocean since 
1990s. Compared with the levels reported over other oceans, the gaseous concentrations of PCBs and HCB fell in the low end of global range, while the levels in the seawater were higher or similar to those in other oceans. The air samples collected near the continents displayed higher PCB levels than those from the open equatorial Indian Ocean. This may be related to land-based emissions, such as storage of obsolete PCB-containing equipments, landfill, incineration of e-waste, and ship-breaking activities. Fugacity fractions suggest that both PCBs and HCB were undergoing net volatilization from the seawater to air in the equatorial Indian Ocean in most cases. The flux values were mostly driven by the concentration gradient and wind speed as well.

\section{Acknowledgments}

This work was supported by the Natural Science Foundation of China (NSFC) (Nos. 41121063, 41125014 and 41073080). In addition, the authors would like to thank Baruch Spiro for revising this manuscript, and thank the National Oceanic and Atmospheric Administration's Air Resources Laboratory for providing the HYSPLIT transport model and the READY website (http://www.arl.noaa.gov/ready.html). This is a contribution of GIGCAS-1812.

\section{Appendix A. Supplementary material}

Supplementary data associated with this article can be found, in the online version, at http://dx.doi.org/10.1016/j.marpolbul.201 4.01.007.

\section{References}

Bamford, H.A., Poster, D.L., Huie, R., Baker, J.E., 2002. Using extrathermodynamic relationships to model the temperature dependence of Henry's Law constants of 209 PCB congeners. Environ. Sci. Technol. 36, 4395-4402.

Booij, K., van Bommel, R. Jones, K.C., Barber, J.L., 2007. Air-water distribution of Hexachlorobenzene and 4,4'-DDE along a North-South Atlantic transect. Mar. Pollut. Bull. 54, 814-819.

Breivik, K., Sweetman, A., Pacyna, J.M., Jones, K.C., 2007. Towards a global historica emission inventory for selected PCB congeners - A mass balance approach-3. An update. Sci. Total Environ. 377, 296-307.

Breivik, K., Gioia, R., Chakraborty, P., Zhang, G., Jones, K.C., 2011. Are reductions in industrial organic contaminants emissions in rich countries achieved partly by export of toxic wastes? Environ. Sci. Technol. 45, 9154-9160.

Dachs, J., Lohmann, R., Ockenden, W.A., Mejanelle, L., Eisenreich, S.J., Jones, K.C., 2002. Oceanic biogeochemical controls on global dynamics of persistent organic pollutants. Environ. Sci. Technol. 36, 4229-4237.

de Voogt, P., Brinkman, U.A.T., 1989. Production, properties and usage of polychlorinated biphenyls. In: Kimbrough, R.D., Jensen, A.A. (Eds.) Halogenated Biphenyls, Terphenyls, Naphthalenes, Debenzodioxins and Related Products. Elsevier, Amsterdam, pp. 3-46.

Draxler, R.R., Rolph, G.D., 2003. NOAA Air Resources Laboratory. In: MD, S.S. (Ed.).

Eckhardt, S., Breivik, K., Mano, S., Stohl, A., 2007. Record high peaks in PCB concentrations in the Arctic atmosphere due to long-range transport of biomass burning emissions. Atmos. Chem. Phys. 7, 4527-4536.

Gioia, R., Nizzetto, L., Lohmann, R., Dachs, J., Temme, C., Jones, K.C., 2008a. Polychlorinated biphenyls (PCBs) in air and seawater of the Atlantic Ocean: Sources, trends and processes. Environ. Sci. Technol. 42, 1416-1422.
Gioia, R., Lohmann, R., Dachs, J., Temme, C., Lakaschus, S., Schulz-Bull, D., Hand, I., Jones, K.C., 2008b. Polychlorinated biphenyls in air and water of the North Atlantic and Arctic Ocean. J. Geophys. Res. 113, D19302. http://dx.doi.org/ 10.1029/2007JD009750.

Gioia, R., Eckhardt, S., Breivik, K., Jaward, F.M., Prieto, A., Nizzetto, L., Jones, K.C., 2011. Evidence for major emissions of PCBs in the west African region. Environ. Sci. Technol. 45, 1349-1355.

Gioia, R., Li, J., Schuster, J., Zhang, Y., Zhang, G., Li, X., Spiro, B., Bhatia, R.S., Dachs, J., Jones, K.C., 2012. Factors affecting the occurrence and transport of atmospheric organochlorines in the China Sea and the Northern Indian and South East Atlantic Oceans. Environ. Sci. Technol. 46, 10012-10021.

Iwata, H., Tanabe, S., Sakai, N., Tatsukawa, R., 1993. Distribution of persistent organochlorines in the oceanic air and surface seawater and the role of ocean on their global transport and fate. Environ. Sci. Technol. 27, 1080-1098.

Jantunen, L.M., Bidleman, T.F., 2006. Henry's law constants for Hexachlorobenzene, p. $\mathrm{p}^{\prime}$-DDE and components of technical chlordane and estimates of gas exchange for Lake Ontario. Chemophere 62, 1689-1696.

Jaward, F.M., Barber, J.L., Booij, K., Dachs, J., Lohmann, R., Jones, K.C., 2004. Evidence for dynamic air-water coupling and cycling of persistent organic pollutants over the open Atlantic Ocean. Environ. Sci. Technol. 38, 2617-2625.

Li, N., Wania, F., Lei, Y.D., Daly, G.L., 2003. A comprehensive and critical compilation, evaluation, and selection of physical-chemical property data for selected polychlorinated biphenyls. J. Phys. Chem. Ref. Data. 32, 1545-1590.

Lohmann, R., Gioia, R., Jones, K.C., Nizzetto, L., Temme, C., Xie, Z., Schulz-Bull, D., Hand, I., Morgan, E., Jantunen, L., 2009. Organochlorine pesticides and PAHs in the surface water and atmosphere of the North Atlantic and Arctic Ocean. Environ. Sci. Technol. 43, 5633-5639.

Lohmann, R., Klanova, J., Kukucka, P., Yonis, S., Bollinger, K., 2012. PCBs and OCPs on an East-to-West transect: the importance of major currents and net volatilization for PCBs in the Atlantic Ocean. Environ. Sci. Technol. 46, 1047110479.

Pozo, K., Harner, T., Lee, S.C., Sinha, R.K., Sengupta, B., Loewen, M., Geethalakshmi, V., Kannan, K., Volpi, V., 2011. Assessing seasonal and spatial trends of persistent organic pollutants (POPs) in Indian agricultural regions using PUF disk passive air samplers. Environ. Pollut. 159, 646-653.

Robinson, B.H., 2009. E-waste: an assessment of global production and environmental impacts. Sci. Total Environ. 408, 183-191.

Schwarzenbach, R.P., Gschwend, P.M., Imboden, D.M., 2003. Environmental Organic Chemistry, second ed. John Wiley \& Sons Inc., Hoboken, NJ, USA, pp. 919-921.

Su, Y., Hung, H., Blanchard, P., Patton, G.W., Kallenborn, R., Konoplev, A., Fellin, P., Li, H., Geen, C., Stern, G., 2006. Spatial and seasonal variations of hexachlorocyclohexanes (HCHs) and hexachlorobenzene (HCB) in the Arctic atmosphere. Environ. Sci. Technol. 40, 6601-6607.

UNEP, 2002. Regional based assessment of persistent toxic substances - Indian Ocean Regional Report. <http://www.chem.unep.ch/pts/regreports/IndianOcean.pdf>, p. 15.

Wong, F., Jautunen, L.M., Pućko, M., Papakyriakou, T., Staebler, R.M., Stern, G.A., Bidleman, T.F., 2011. Air-water exchange of anthropogenic and natural organohalogens on International Polar Year (IPY) expeditions in the Canadian Arctic. Environ. Sci. Technol. 45, 876-881.

Wurl, O., Potter, J.R., Obbard, J.P., Durville, C., 2006. Persistent organic pollutants in the equatorial atmosphere over the open Indian Ocean. Environ. Sci. Technol. 40, 1454-1461.

Zhang, L., Lohmann, R., 2010. Cycling of PCBs and HCB in the surface ocean-lower atmosphere of the open ocean. Environ. Sci. Technol. 44, 3832-3838.

Zhang, G., Li, J., Cheng, H., Li, X., Xu, W., Jones, K.C., 2007. Distribution of organochlorine pesticides in the Northern South China Sea: implications for land outflow and air-sea exchange. Environ. Sci. Technol. 41, 3884-3890.

Zhang, G., Chakraborty, P., Li, J., Sampathkumar, P., Balasubramanian, T., Kathiresan, K., Takahashi, S., Subramanian, A., Tanabe, S., Jones, K.C., 2008. Passive atmospheric sampling of organochlorine pesticides, polychlorinated biphenyls, and polybrominated diphenyl ethers in urban, rural, and wetland sites along the coastal length of India. Environ. Sci. Technol. 42, 8212-8223.

Zhang, L., Bidleman, T.F., Perry, M.J., Lohmann, R., 2012. Fate of chiral and achiral organochlorine pesticides in the North Atlantic bloom experiment. Environ. Sci. Technol. 46, 8106-8114. 